1916, pp. 53-66, 7 figs.) in which he discusses the synonymy of Lasius and its subgenera. He accepts Jurine's Lasius as valid and substitutes Formicina Shuckard for Lasius Fabricius, presenting the same arrangement of the subgenera and their types as I have given on page 170. I am still unable to take this view of the matter, because I am not convinced that the generic name of another author (in this case Jurine) is valid when cited in an anonymous paper which itself has no taxonomic status. It would seem that if an anonymous author later acknowledges the authorship of his paper, the validity of the latter should date only from the time of this acknowledgment. If this rule were followed, Lasius Jurine would date from 1806 and could not replace Lasius Fabricius of 1804.

\title{
A PHOSPHORESCENT ANT.
}

\section{By William Morton Wheeler, Bussey Institution, Harvard University.}

Mr. George P. Engelhardt, curator of the Division of Invertebrates of the Brooklyn Museum, recently sent me the following letter and the ant to which it refers:

\section{"My dear Prof. Wheeler:}

"San Francisco, Calif., Aug. 8, 1916.

"One of my most interesting days on the Pacific Coast this summer was spent with Fordyce Grinnell on a thirty-mile tramp through the Sierra Madre, July 28. Starting from Pasadena we followed the Arroyo Seco to the Divide, came up around Mount Gabriel (6,150 feet) and reached Mount Lowe (5,650 feet) in time for a glorious sunset. Our descent from Mount Lowe was made over the steep and winding ridge trail after dark. There was no moon, but a star-studded sky, while 5,000 feet below Pasadena and Los Angeles had been transformed into a sea of sparkling lights.

"Down at about the 4,000 feet level we stopped before a bright spark rapidly crossing the trail. Expecting to find one of the Lampyrids, or fireflies, which Grinnell told me were uncommon in the region, we struck a match and to our surprise found an ant. Neither of us had heard of phosphorescent ants before. In a 
cyanide tube the phosphorescence of the ant remained undiminished for fully five minutes, after which it decreased gradually and in fifteen minutes disappeared. The light issued ventrally from the last two or perhaps three abdominal segments. It was greenish yellow, and very much like that of our common eastern firefly, only it was constant, not intermittent

"We kept a sharp look-out all the way down the trail, but no other specimens were found.

$$
\text { "Very sincerely yours, }
$$

The ant proves to be a worker media of Camponotus maculatus Fabr., subsp. vicinus Mayr., var. semitestaceus Emery, a form peculiar to higher elevations in the Californian Coast Range. It is the palest of several varieties of vicinus, which ranges as far east as Colorado and Montana and as far south as Arizona and New Mexico. The yellow color of the var. semitestaceus shows that it is nocturnal, but my observations lead me to suspect that the darker forms of vicinus have the same habit. As no ants are known to possess photogenetic organs, and as $C$. maculatus is of world-wide distribution and represented by many yellow subspecies and varieties especially in North Africa and Asia Minor, where any tendency to phosphorescence would certainly have been seen and noted, I conclude that the specimen taken by Mr. Engelhardt must either have just fed on some phosphorescent organism or have been infected with phosphorescent bacteria. Although Dr. Rudolph Glaser went to some pains to section and stain the hard abdomen of the specimen for me, I was unable to detect any structures that might account for the luminescence. This failure was in great part due, in all probability, to the imperfect preservation of the ant, which had merely been dropped into strong alcohol. The problem of the source of the greenish yellow light emitted by the posterior abdominal segments and witnessed by Messrs. Engelhardt and Grinnell will, therefore, require fresh material for its solution and must be referred to some entomologist residing in California. 

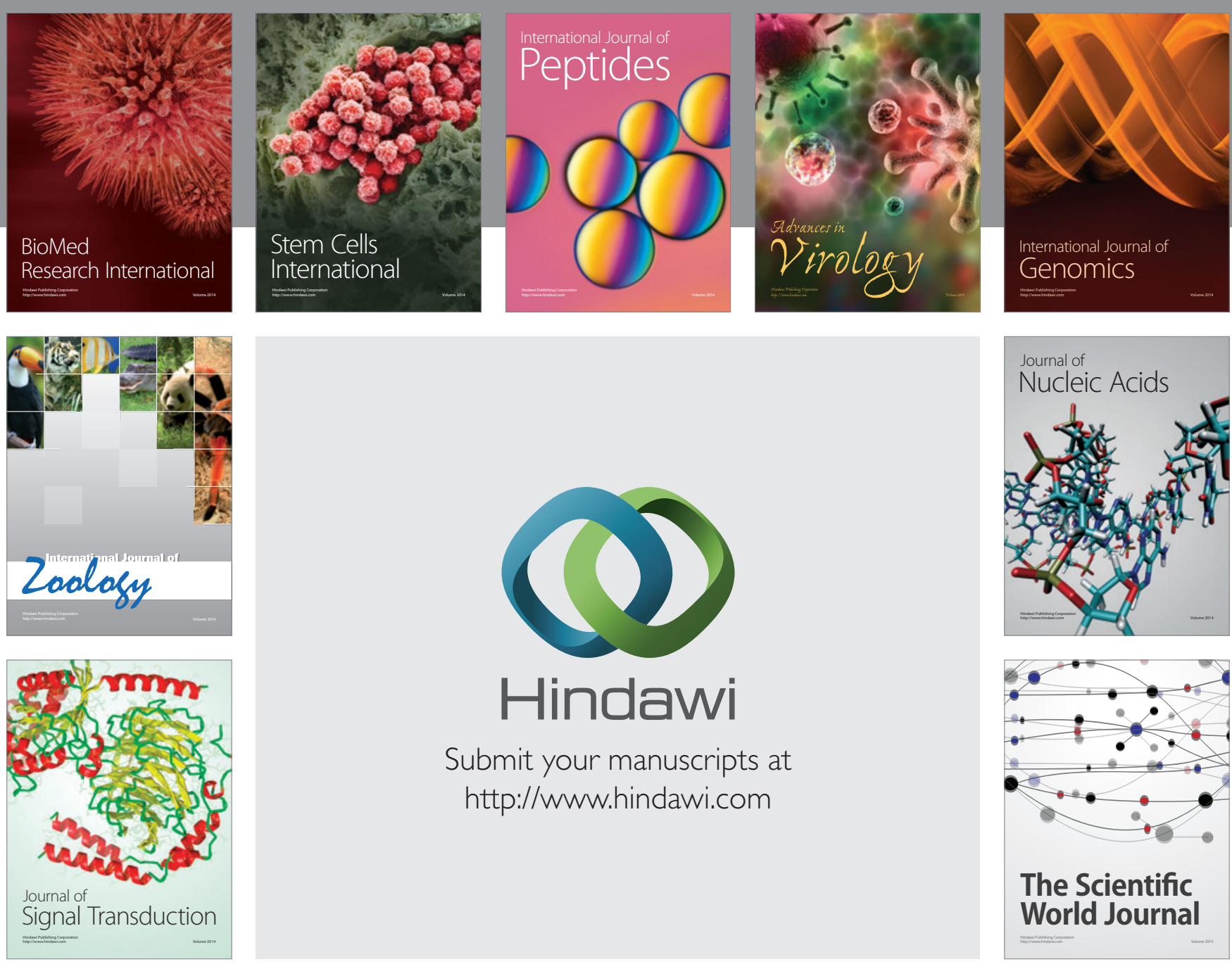

Submit your manuscripts at

http://www.hindawi.com
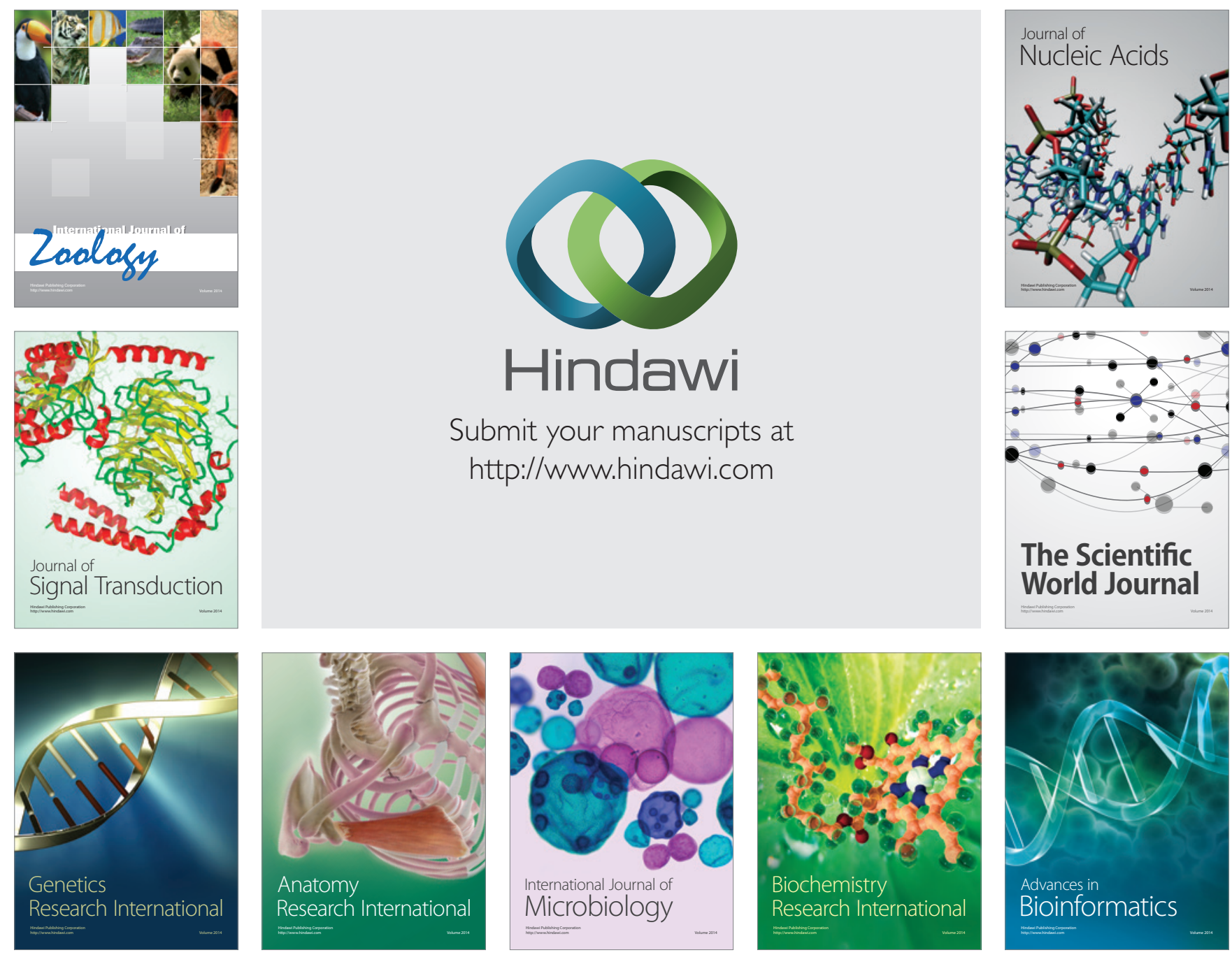

The Scientific World Journal
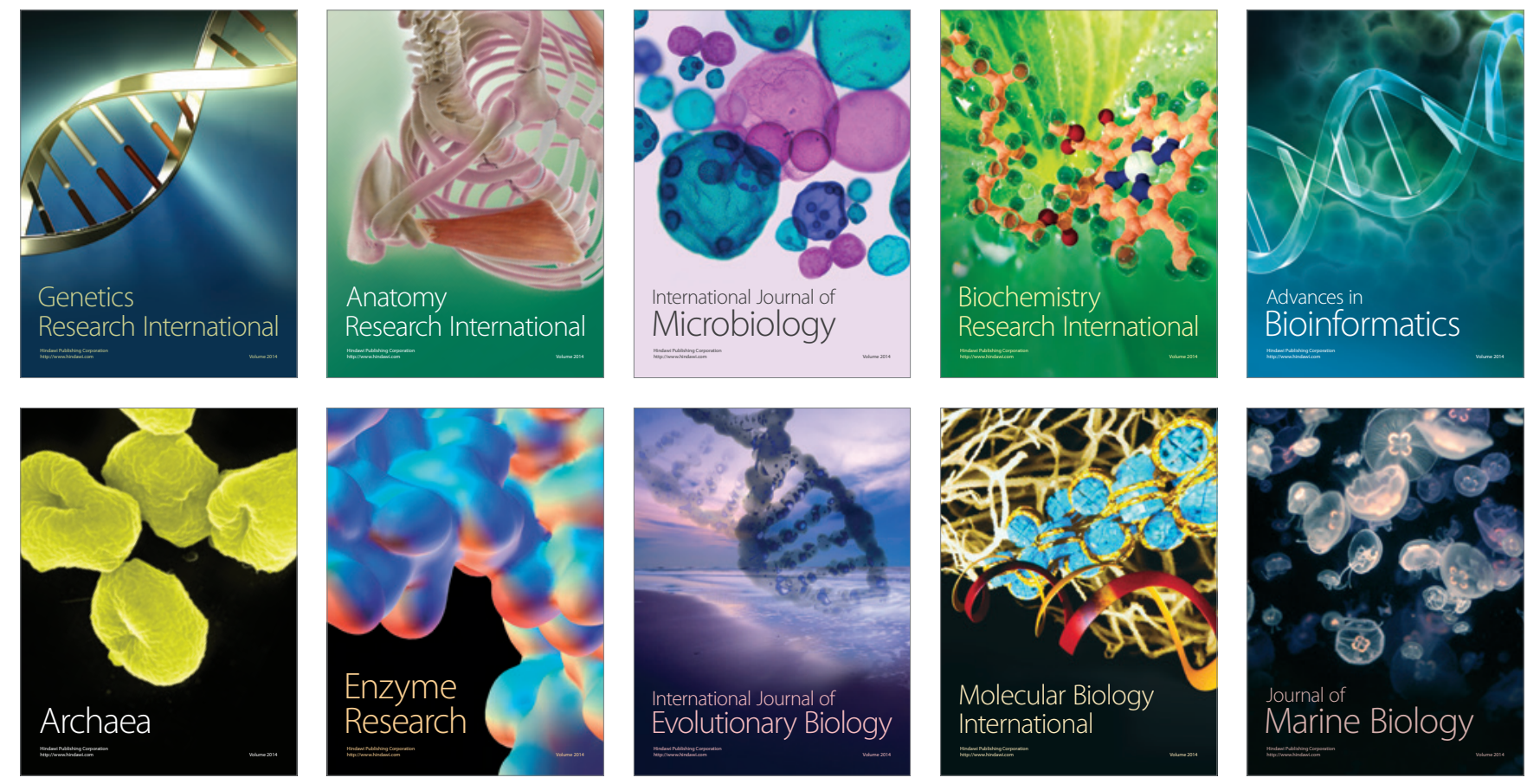